\title{
Indoor air quality in preschools (3- to 5-year-old children) in the Northeast of Portugal during spring- summer season: pollutants and comfort parameters
}

\author{
Marta Oliveira,Klara Slezakova,Cristina Delerue-Matos, Maria do Carmo Pereira \& Simone Morais
}

aREQUIMTE-LAQV, Instituto Superior de Engenharia do Porto, Instituto Politécnico do Porto, Porto, Portugal; bLEPABE, Departamento de Engenharia Química, Faculdade de Engenharia, Universidade do Porto, Porto, Portugal

\begin{abstract}
Indoor air quality at schools (elementary, primary) has been the subject of many studies; however, there are still relative few data regarding preschool (3- to 5-year-old children) environments. This investigation determined the concentrations of particulate matter (PM)2.5, total volatile organic compounds (TVOC), formaldehyde, carbon monoxide ( $\mathrm{CO}$ ), and ozone (O3) as well as the levels of carbon dioxide (CO2), temperature, and relative humidity $(\mathrm{RH})$ in the indoor and outdoor air of two preschools situated in different geographical regions of Portugal. The indoor concentrations of TVOC, $\mathrm{CO}, \mathrm{O} 3$, and $\mathrm{CO} 2$ were predominantly higher at the end of school day compared to early morning periods. The TVOC and $\mathrm{CO} 2$ concentrations were higher indoors than outdoors suggest- ing predominantly an indoor origin. Outdoor air infiltrations were the major contributing source of $\mathrm{CO}$ and $\mathrm{O} 3$ to indoor air in both preschools. The concentrations of all pollutants were within the limits defined by national regulations and international organizations, except for TVOC that exceeded 8-12-fold higher than the recommendation of 0.2 $\mathrm{mg} / \mathrm{m} 3$ proposed by European Commission. The levels of $\mathrm{CO} 2$ were below the protective guideline of $2250 \mathrm{mg} / \mathrm{m} 3$ (Portuguese legislation); however, the observed ranges exceeded the Portuguese margin of tolerance (2925 $\mathrm{mg} / \mathrm{m3}$ ) at the end of school days, indicating the impact of occupancy rates particularly at one of the preschools. Regarding comfort parameters, temperature exerted a significant influence on $\mathrm{O} 3$ concentrations, while $\mathrm{RH}$ values were significantly correlated with TVOC levels in indoor air of preschools, particularly during the late afternoon periods.
\end{abstract}




\section{Introduction}

Outdoor air pollution is a worldwide concern, which was recently classified as carcinogenic to humans by the International Agency for Research on Cancer (IARC) (group 1; IARC, 2016) as there is sufficient evidence to indicate that air contaminants are attrib- uted to cause lung cancer. Exposure to outdoor air pollutants has also been associated with an increased risk of developing cancer of the urinary bladder (IARC, 2016). Several investigators have focused on indoor air quality (IAQ) since individuals spend large portion of time indoors. Factors that predomi- nantly affect IAQ include the existence of various indoor emission sources such as various indoor equipment, human activities, emissions released from buildings through its construction materials, infiltration of outdoor air, and ventilation deficien- cies (Fernández et al., 2013; WHO, 2010). Special attention needs to be given to compounds that may produce and/or potentiate the development of adverse health problems (WHO, 2010). It is note- worthy that the WHO (2010) included formalde- hyde (group 1-carcinogenic to humans; IARC, 2006) and carbon monoxide (CO) as relevant indoor air pollutants, while monitoring of particulate matter (PM), $\mathrm{CO}$, and ozone (O3) was recommended for outdoor air (WHO, 2006). As a consequence, $\mathrm{PM}_{10}$ and $\mathrm{PM}_{2} .5$ (particulate matter with 10 and $2.5 \mu \mathrm{m}$ of aerodynamic diameter, respectively), total volatile organic compounds (TVOC), formaldehyde, $\mathrm{CO}$, and $\mathrm{O}_{3}$ are among the compounds included in the list of pollutants that need to be monitored in indoor air in Portuguese buildings (Decreto Lei no 18-2013; Portaria no. 353-A/2013). Once inhaled, PM10 is deposited in the upper respiratory system, whereas $\mathrm{PM}_{2.5}$ and smaller particles penetrate deeply into the lungs and deposit in the smaller conducting airways and gas exchange regions of lungs (Costa et al., 2014; Kim et al., 2013). The indoor levels of pollutants are influenced by occupation rates and local atmo- spheric conditions. Indoor temperature $(\mathrm{T})$ and rela- tive humidity $(\mathrm{RH})$ may also contribute to accumulation of indoor pollutants (Huang et al., 2016; Sakaietal.,2004; Wolkoff \& Nielsen, 2010).

Young children are one of the most vulnerable population groups as their respiratory, immune, reproductive, central nervous, and digestive sys- tems are not completely developed (Bateson \& Schwartz, 2008; Burtscher \& Schüepp, 2012; Madureira et al., 2015; Makri et al., 2004; Salvi, 2007). In modern society, 3- to 5-year-old children spend up to $85 \%$ of their time at homes and/or premises in education settings, namely nurseries, kindergartens, day-care centers, and preschools. These environments constitute children first social integrations, after homes being the places where they spend the majority of their times (approxi- mately 7-8 hr per day). Most of the available studies have focused on children's exposure to indoor air pollutants at primary and elementary schools (Alves et al., 2014; AnnesiMaesano et al., 2012, 2013; Bakó-Biró et al., 2012; Demirel et al.,2014; Ferreira and Cardoso, 2013, 2014; Guo et al.,2010; Macedo et al., 2013; Madureira et al., 2012,2014, 2015; Pegas et al., 2010, 2011a, 2011b, 2012; Cavaleiro Rufo et al., 2015). IAQ in preschools may vary from primary and higher learning schools due to different conducted activities and behavioral patterns, building, and environmental characteristics including construction materials, cleaning, and ventilation habits (Yang et al., 2009; Vassura et al., 2015; Wichmann et al., 2010). Thus, it would seem that children exposure in preschools may vary from older students' envir- onments. During the last years, some studies con- cerning exposure of young children, that is, less than 5 years, to indoor air pollutants at educa- tional microenvironments 
were reported for: 1) nurseries (Branco et al., 2014, 2015a, 2015b; Mainka et al., 2015; Nunes et al., 2015, 2016), 2) day-care centers and kindergartens (Araújo- Martins et al., 2014; Carreiro-Martins et al., 2014; Cyprowski et al., 2013; Gładyszewska-Fiedoruk, 2013; Yang et al., 2009), and 3) preschools (Fonseca et al., 2014; Latif et al., 2014; Mainka \&Zajusz-Zubek, 2015; Oliveira et al., 2015a, 2015b, 2015c, 2016a, 2016b, 2016c; Slezakova et al., 2015; Rawi et al., 2015; Vassura et al., 2015; Wichmann et al., 2010; Yoon et al., 2011). Some of these investigations mainly focused on ventilation and/ or carbon dioxide $\left(\mathrm{CO}_{2}\right)$ levels as a global IAQ indicator (Branco et al., 2015a; Carreiro-Martins et al., 2014; Gładyszewska-Fiedoruk, 2013; Latif et al., 2014; Mainka \& Zajusz-Zubek, 2015). In Portugal, limited information is available regard- ing preschool children (3-5 years old) exposure to some of the most relevant indoor contaminants at preschools (Fonseca et al., 2014; Oliveira et al., 2015a, 2015b, 2015c, 2016a, 2016b, 2016c;

Slezakova et al., 2015). Further, none of the avail- able studies apparently examined different periods of the day and did not explore the influence of comfort parameters on the levels of indoor pollutants.

The aim of the present study was to: i) monitor the levels of $\mathrm{PM}_{2} .5, \mathrm{TVOC}$, formaldehyde, $\mathrm{CO}$, and $\mathrm{O}_{3}$ simultaneously in indoor and outdoor air in two urban Portuguese preschools; ii) examine the impact of comfort parameters, namely $\mathrm{CO}_{2}, \mathrm{~T}$, and $\mathrm{RH}$ on indoor levels of pollutants; iii) determine the concentrations of studied $\mathrm{PM}_{2} .5$ and gaseous pollutants according to the existing guidelines and references for IAQ.

\section{Materials and methods}

\section{Characterization of sampling sites}

Preschools are educational establishments dedi- cated to learning and social development of 3- to 5-yearold children before their attendance at pri- mary schools. In 2013, a total of 6429 public and private preschools operated in Portugal with 266,666 registered children (3-5 years old) (Pordata, 2016). Particulate matter2.5, four gaseous pollutants (TVOC, formaldehyde, $\mathrm{CO}$, and $\mathrm{O}_{3}$ ) and three comfort parameters $\left(\mathrm{CO}_{2}, \mathrm{~T}\right.$, and $\left.\mathrm{RH}\right)$ were simultaneously monitored in indoor and outdoor air of two Portuguese preschools located in different geographical regions (Figure 1). One of the selected preschools (P1) was located in Oporto Metropolitan Area (north of Portugal), the second most densely populated city of the country. In 2013, 44,467 children attended in a total of 151 public and private preschools located in that metropolitan area (Pordata, 2016). 

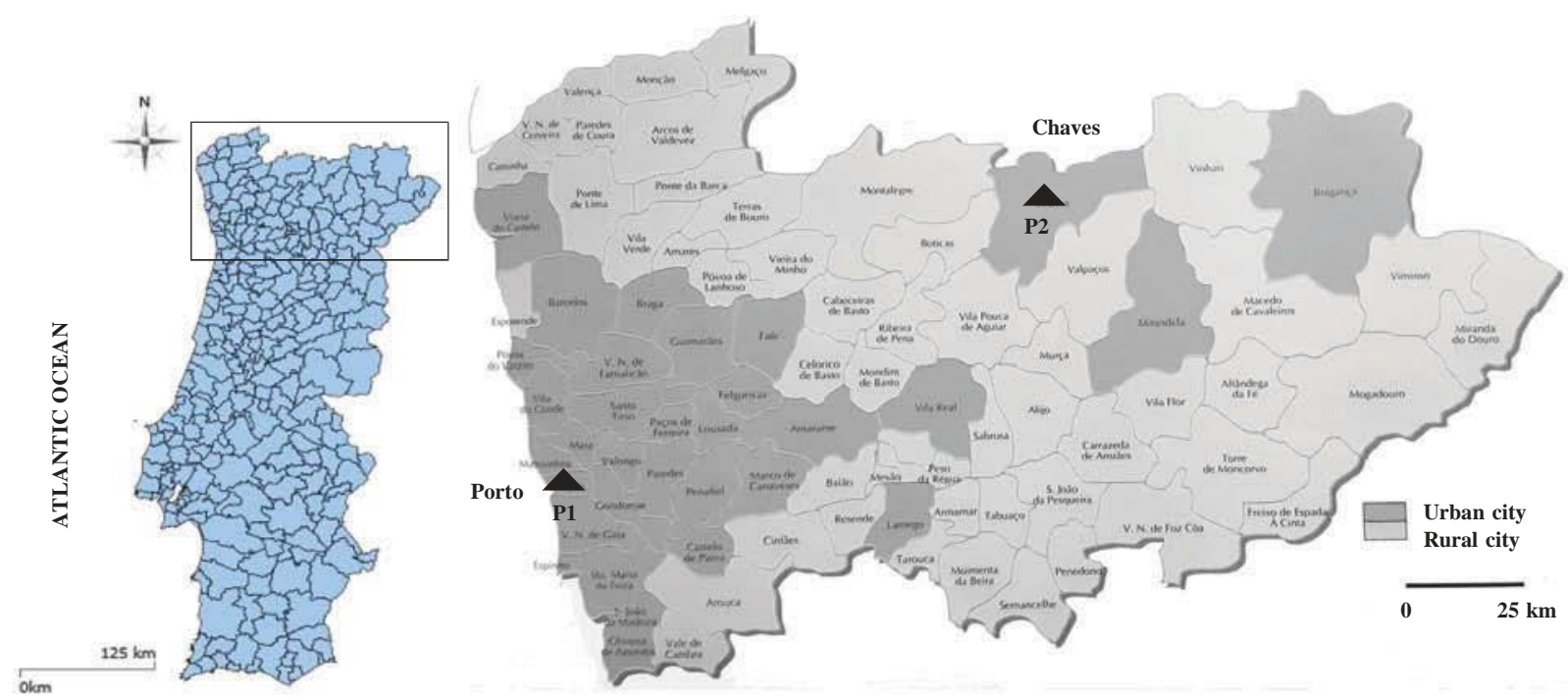

Figure 1. Geographical location of preschools P1 (Oporto) and P2 (Chaves).

Preschool P1 was situated in an urban zone of Oporto city in a close proximity (less than $1000 \mathrm{~m}$ ) to an exit of one of the major highways sur- rounding the city. The mean traffic density in the streets surrounding the preschool was 16 cars/ min, which increased to 27 and $25 \mathrm{cars} / \mathrm{min}$ dur- ing peak hr of 8 a.m. and 6 p.m., respectively. Preschool P2 was situated in Chaves, the second largest city of the district of Vila Real (north of Portugal) where a total of 787 children were regis- tered in 2013 at 35 public and private preschools (Pordata, 2016). P2 was located in the main traffic street that provides direct access to Chaves city center. Immediately in the back area of that pre- school, there was a main city shopping center with a petrol station, which generated a moderate traf- fic density throughout the day (5 cars/min). The traffic density also rose at peak rush $\mathrm{hr}(7 \mathrm{cars} / \mathrm{min}$ around $8 \mathrm{a} . \mathrm{m}$. and $10 \mathrm{cars} / \mathrm{min}$ at 6 p.m.). Both urban-traffic preschools were constructed before 1950 and present a two-floor building structure with a 2-3 m brick-wall base. P1 pre- sented a fence with $4 \mathrm{~m}$ above the brick wall. The main structural characteristics of both preschools and meteorological conditions data (solar radia- tion, wind speed, and precipitation) are provided in Table 1S (Supplementary Material).

A total of 173 and 44 preschool children (3-5 years old) were enrolled at P1 and P2, respectively.

An example of children activity and time patterns of 3 -year-old children from both preschools is presented in Table 2S. During the sampling cam- paigns, a total of 18-40 and 16-22 children $(<1$ student $/ \mathrm{m}^{2}$ ) were present in the rooms of $\mathrm{P} 1$ and $\mathrm{P} 2$, respectively.

The selected indoor microenvironments were ventilated through the opening of windows during two particular periods of the school day: i) 5-10 min before children arrivals at school (around 8 a.m.) and approximately during 5-20 min after the end of school day when the room was empty (after 6 p.m.). None of the preschool rooms had mechanical ventilation system. During classes including when some physical activities were per-formed indoors the doors were closed except dur- ing recesses. At night, all windows and doors were kept closed. Both preschool rooms were equipped with closets and/or shelves with stock of art-craft supplies (gouaches, inks, glues). In addition, chil- dren' hand-made 
paintings were hung in rooms and/or glued to the walls at P2 classroom. P1 and P2 rooms were cleaned daily at the end of the school day.

\section{Sample collection}

Gaseous pollutants and comfort parameters were monitored during 10 consecutive weeks between April and June 2013 at both preschools. Sampling campaigns were performed in an educational playroom (P1) and in one classroom (P2). Both selected rooms were used during the school day for classes and several activities including handi- works with different materials, musical classes, reading, playing, and physical exercises.

PM2.5 masses were gravimetrically determined by collection on polytetrafluoroethylene mem- brane filters ( $\varnothing 47 \mathrm{~mm}$, SKC Ltd., Dorset, UK) with a setup of low-flow (38.3 L/min) pumps (models Bravo H2; TCR TECORA, Paris, France) that were connected to PM EN LVS sampling head (in accordance with norm EN14907). PM2.5 sam- pling was conducted continuously for a period of $24 \mathrm{hr}$ over 5 week days $(n=50)$. The concentrations of TVOC, $\mathrm{CO}, \mathrm{CO}_{2}$, and $\mathrm{O}_{3}$ were measured twice per day at each preschool: i) in early morning between 8 and 9 a.m. which corresponded to the period of children arrivals and ii) in late afternoon between 4 and 5 p.m. before the children left pre- schools. Monitoring was performed for 15-20 min periods (with a logging interval of $30 \mathrm{sec}$ by a multi-gas sensor probe (model TG 502; GrayWolf Sensing Solutions, Shelton, USA) during each weekday, i.e., from Monday morning to Friday afternoon). The concentrations of formaldehyde were registered with a Formaldemeter ${ }^{\mathrm{TM}}$ (model htV-M; PPM Technology, Caernarfon, UK). Equipment was calibrated by manufacturers before the beginning of sampling campaigns, and the analytical response was checked daily according to manufacturer specifications. All parameters were monitored at the breathing level of preschool children (approximately at $0.4-1 \mathrm{~m}$ above the floor) and preferably in the center of the rooms in order to minimize the influence of outdoor sources. The levels of PM2.5 $(n=50)$ gaseous pollu- tants and $\mathrm{CO}_{2}$ were concomitantly monitored in the outdoor areas of each preschool. Measurements were conducted in places where the sampling interferences from trees, walls, and/ or fences would be minimal. Indoor and outdoor $\mathrm{T}$ and $\mathrm{RH}$ were monitored by Testo mini data- logger (model 174H; Testo AG, Lenzkirch, Germany). Precaution was taken to ensure the safety of children. Indoor potential source activ- ities, number of children, door, and window posi- tions, as well as ventilation status were registered daily in selected indoor rooms.

\section{Data analysis}

Statistical treatment was performed using SPSS (IBM SPSS Statistics 20) and statistical software (v. 7, StatSoft Inc., USA). Statistical significance was defined as $p \leq 0.05$.

Results 
The mean and range concentrations of $\mathrm{PM}_{2} .5$ in indoor air of preschools $\mathrm{P} 1$ and $\mathrm{P} 2$ are illustrated in Figure 2a.
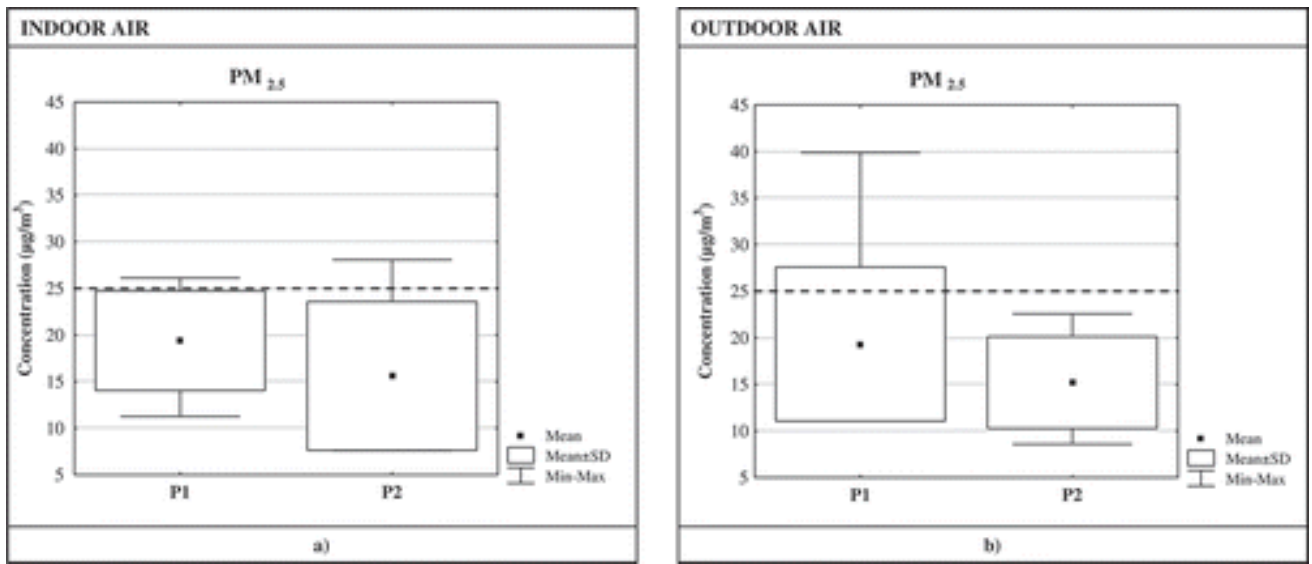

Figure 2. PM2.5 concentrations in indoor (a) and outdoor (b) air of preschools P1 and P2. The horizontal dashed lines represent guideline values of $25 \mathrm{\mu g} / \mathrm{m3}$ (Portuguese Regulation, 2013; WHO, 2006 WHO. 2006. World Health Organization. Air Quality Guidelines Global Update 2005. Copenhagen, Denmark: World Health Organization Regional Office for Europe.

There were no significant differences $\left(11.2-26.1 \mu \mathrm{g} / \mathrm{m}^{3}\right.$ at $\mathrm{P} 1$ and $7.58-28.1 \mu \mathrm{g} / \mathrm{m}^{3}$ at $\left.\mathrm{P} 2\right)$ detected. The levels of indoor TVOC, $\mathrm{CO}$, and $\mathrm{O}_{3}$ during early morning and late afternoon periods at preschools $\mathrm{P} 1$ and P2 are presented in Figure 3. The concentrations of gaseous pollutants inside rooms ranged widely throughout the day. At both preschools, the levels of TVOC, $\mathrm{CO}$, and $\mathrm{O}_{3}$ were significantly higher at the end of the school day than at early morning period, except for TVOC and CO at P2 (Figure 3). Intercomparison between preschool indoor air revealed that con- centrations of TVOC (P1: $1.84 \pm 1.24$ $\mathrm{mg} / \mathrm{m}^{3}$ and $2.5 \pm 0.81 \mathrm{mg} / \mathrm{m}^{3} ; \mathrm{P} 2: 2.5 \pm 0.52 \mathrm{mg} / \mathrm{m}^{3}$ and $1.67 \pm$

$0.67 \mathrm{mg} / \mathrm{m}^{3}$, respectively, for early morning and late afternoon periods) and formaldehyde (0.03 \pm 0.02 ; $0.01-0.06 \mathrm{mg} / \mathrm{m}^{3}$ at $\mathrm{P} 1$ versus $0.04 \pm 0.02 ; 0.01-0.09 \mathrm{mg} / \mathrm{m}^{3}$ at P2) were higher at P2 (Figure 3; Table 1). The concentrations of formal- dehyde in indoor air of both preschools reached maximal values of 0.06 and $0.09 \mathrm{mg} / \mathrm{m}^{3}$, respec- tively, at P1 and P2 (Table 1). At preschool yards, formaldehyde concentrations were always below the limit of detection (LOD) of the equipment $\left(12.5 \mu \mathrm{g} / \mathrm{m}^{3}\right)$. In addition, P1 displayed markedly higher levels of $\mathrm{CO}$ (2.5-fold) and $\mathrm{O}_{3}$ (2.4-fold) than P2. Regarding $\mathrm{CO}_{2}$, indoor concentrations $\left(796-3606 \mathrm{mg} / \mathrm{m}^{3}\right.$ at $\mathrm{P} 1 ; 686-2686 \mathrm{mg} / \mathrm{m}^{3}$ at $\left.\mathrm{P} 2\right)$ were significantly greater between both preschools only for late afternoon periods (Figure 4). Finally, regarding other comfort parameters, both indoor means of $T$ and $R H$ rose numerically (11 for $T$ and $1.2 \%$ for $R H$ ) from the morning to the afternoon periods at P1. At P2, the indoor T increased $23 \%$, while $\mathrm{RH}$ fell by $43 \%$ (Table 2 ). 

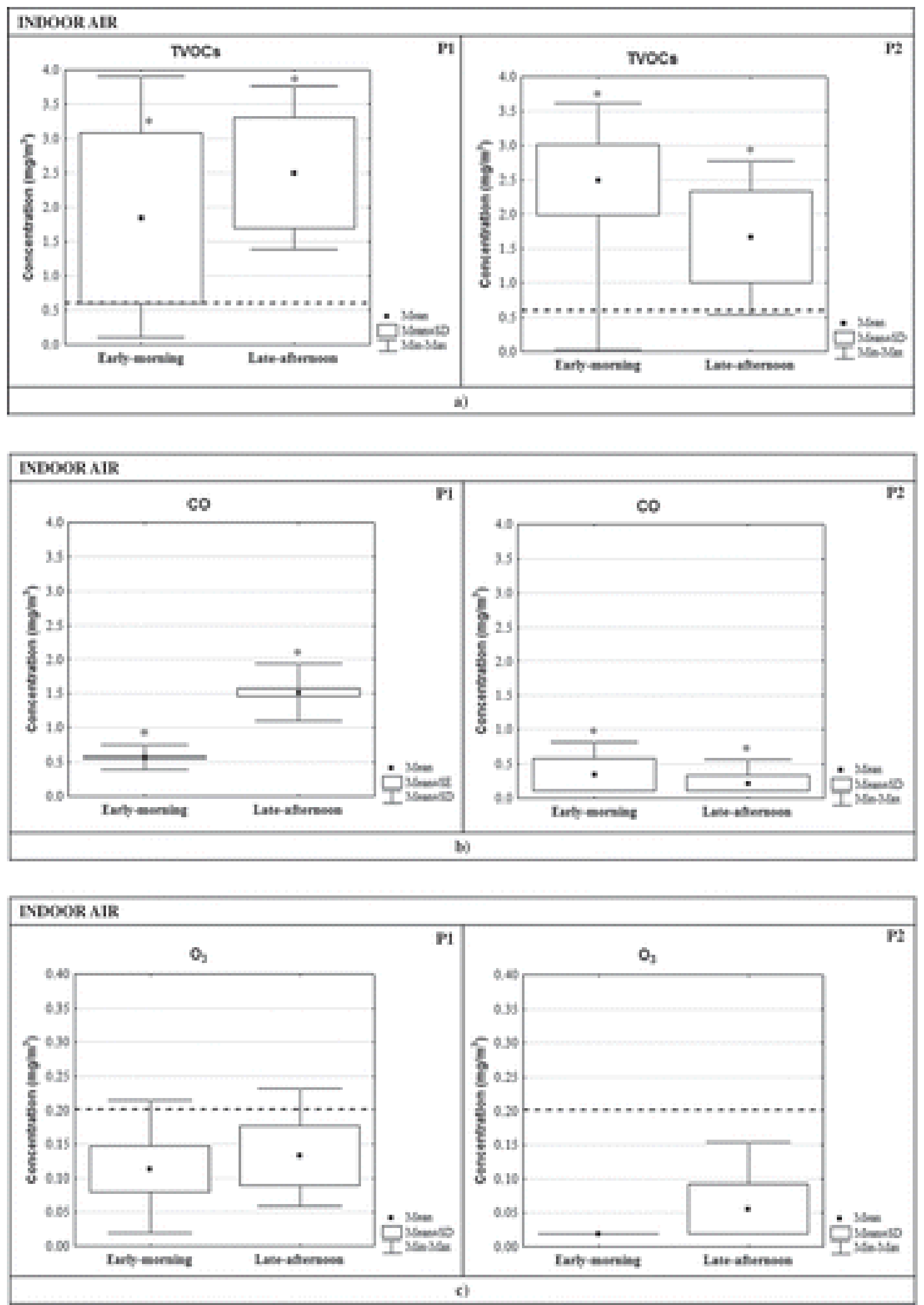

Figure 3. Levels of indoor gaseous pollutants: a) total volatile organic compounds (TVOC); b) carbon monoxide (CO); c) ozone (O3) in indoor air of the studied preschool P1 and P2 $(\mathrm{mg} / \mathrm{m} 3)$. The horizontal dashed lines represent guideline values of $0.6 \mathrm{mg} / \mathrm{m} 3 \mathrm{for}$ TVOC and maximum reference concentration of $0.2 \mathrm{mg} / \mathrm{m} 3$ for $\mathrm{O} 3$ in indoor air of Portuguese buildings (Nota Técnica NT-SCE-02, 2006 Nota Técnica NT-SCE-02. 2006; Portaria no. 353-A/2013). *Significant differences ( $\leq 0.05$ ) for nonparametric Mann-Whitney $U$-test between early morning and late afternoon pollutant concentrations for each preschool. 

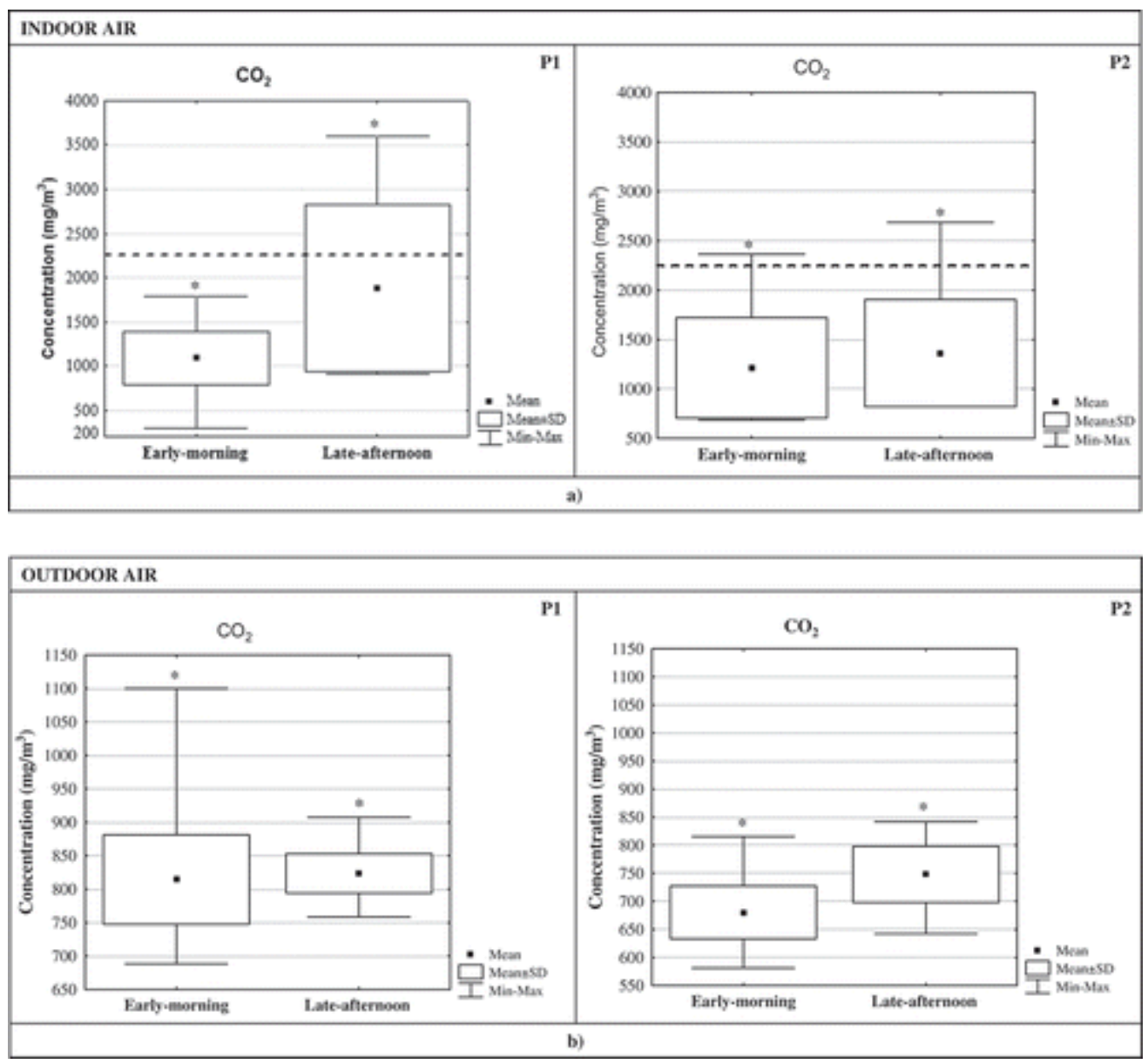

Figure 4. Concentrations of carbon dioxide (CO2) at preschools P1 and P2 in: a) indoors; b) outdoor school areas. The horizontal dashed line represents Portuguese indoor guideline values of $2250 \mathrm{mg} / \mathrm{m3}$ (Portaria no. 353-A/2013) ${ }^{\star}$ Significant differences at $\mathrm{p} \leq 0.05$ for nonparametric Mann-Whitney U-test between early morning and late afternoon levels for each preschool.

The concentrations of $\mathrm{PM} 2.5$ in outdoor air of $\mathrm{P} 1$ and $\mathrm{P} 2$ are given in Figure $2 \mathrm{~b}$. No significant differences were observed between both schools. The concentrations of gaseous pollutants in ambi- ent air of both preschools are shown in Figure 5. The ambient levels of TVOC were markedly higher in the early morning $\mathrm{hr}$ than at the end of the day at both preschools. Further, early morning TVOC concentrations were significantly higher at P2 than at P1. CO and $\mathrm{O}_{3}$ levels were significantly higher in late afternoon period than in early morn- ing hr at $\mathrm{P} 1$, while at $\mathrm{P} 2$, only the mean concen- trations of $\mathrm{O}_{3}$ were significantly higher at the end of the school day. Similar to the findings for indoor air, early morning and late afternoon ambi- ent concentrations of $\mathrm{CO}_{2}\left(814\right.$ and $824 \mathrm{mg} / \mathrm{m}^{3}$ at $\mathrm{P} 1$ versus 680 and $748 \mathrm{mg} / \mathrm{m}^{3}$ at P2), $\mathrm{CO}\left(0.62\right.$ and $1.81 \mathrm{mg} / \mathrm{m}^{3}$ at $\mathrm{P} 1$ versus 0.41 and $0.62 \mathrm{mg} / \mathrm{m}^{3}$ at P2; $1.5-3$-fold higher), and $\mathrm{O}_{3}\left(0.15\right.$ and $0.26 \mathrm{mg} / \mathrm{m}^{3}$ at $\mathrm{P} 1$ versus 0.05 and $0.19 \mathrm{mg} / \mathrm{m}^{3}$ at $\mathrm{P} 2 ; 1.4-3$ - fold higher) were significantly greater at P1 than at P2. Throughout the day, mean values of outdoor T rose 29 and $41 \%$, while 
$\mathrm{RH}$ decreased 29 and $37 \%$, respectively, at P1 and P2 (Table 2).

Table 2 of 2

Table 2. Indoor and outdoor levels (mean and standard deviation; range) of temperature (T) and relative humidity (RH) at the preschools P1 and P2.

\begin{tabular}{|c|c|c|c|c|}
\hline & \multicolumn{2}{|c|}{ Indoor air } & \multicolumn{2}{|c|}{ Outdoor air } \\
\hline & $T\left({ }^{\circ} \mathrm{C}\right)$ & RH (\%) & $T\left({ }^{\circ} \mathrm{C}\right)$ & RH (\%) \\
\hline \multicolumn{5}{|l|}{$\mathrm{P}_{1}$} \\
\hline & $25.4 \pm 2.1$ & $42.7 \pm 13.7$ & $25.5 \pm 4.3$ & $42.1 \pm 18.8$ \\
\hline & $(21.8-32.0)$ & $(19.6-71.2)$ & $(17.3-36.1)$ & $(17.0-89.6)$ \\
\hline \multirow[t]{2}{*}{\begin{tabular}{|l|} 
Early morning \\
\end{tabular}} & $24.8 \pm 1.6$ & $42.6 \pm 14.6$ & $23.2 \pm 2.8$ & $45.5 \pm 21.1$ \\
\hline & $(21.8-28.2)$ & $(19.6-71.2)$ & $(17.3-30.8)$ & $(17.0-89.6)$ \\
\hline \multirow[t]{2}{*}{ Late afternoon } & $27.5 \pm 2.3$ & $43.1 \pm 9.6$ & $30.1 \pm 3.0$ & $35.2 \pm 10.1$ \\
\hline & $(24.6-32.0)$ & $(30.9-57.2)$ & $(26.5-36.1)$ & $(22.0-51.6)$ \\
\hline \multicolumn{5}{|l|}{\begin{tabular}{|l|} 
P2 \\
\end{tabular}} \\
\hline & $20.6 \pm 3.1$ & $54.0 \pm 11.8$ & $19.9 \pm 5.7$ & $51.4 \pm 15.7$ \\
\hline & $(14.4-29.4)$ & $(24.6-74.5)$ & $(12.4-29.4)$ & $(24.7-77.3)$ \\
\hline \multirow[t]{2}{*}{\begin{tabular}{|l|} 
Early morning \\
\end{tabular}} & $18.7 \pm 1.9$ & $62.5 \pm 4.9$ & $16.4 \pm 2.9$ & $59.6 \pm 10.6$ \\
\hline & $(14.4-21.5)$ & $(48.8-74.5)$ & $(12,8-23,0)$ & $(42.5-77.3)$ \\
\hline \multirow[t]{2}{*}{ Late afternoon } & $23.0 \pm 2.7$ & $43.7 \pm 9.1$ & $23.2 \pm 5.7$ & $43.5 \pm 15.7$ \\
\hline & $(19.9-29.4)$ & $(24.6-56.2)$ & $(12.4-29.4)$ & $(24.7-76.5)$ \\
\hline
\end{tabular}

\section{Indoor-to-outdoor ratios}

The levels of TVOC and $\mathrm{CO}_{2}$ were significantly higher in indoor air compared with outdoors (TVOC: 1.84 versus $1.4 \mathrm{mg} / \mathrm{m}^{3}$ for early morning $\mathrm{hr}$ and 2.5 versus $1.3 \mathrm{mg} / \mathrm{m}^{3}$ during late after- noon periods at $\mathrm{P} 1,2.5$ versus $1.91 \mathrm{mg} / \mathrm{m}^{3}$ at morning $\mathrm{hr}$ and 1.67 versus $1.21 \mathrm{mg} / \mathrm{m}^{3}$ at the end of the school day at P2; CO2: 1090 versus $814 \mathrm{mg} / \mathrm{m}^{3}$ during the morning and 1881 versus $824 \mathrm{mg} / \mathrm{m}^{3}$ at the end of afternoons at $\mathrm{P} 1,1213$ versus $680 \mathrm{mg} / \mathrm{m}^{3}$ during early morning periods and 1362 versus 748 $\mathrm{mg} / \mathrm{m}^{3}$ during the end of school day at P2). Mean indoor-to-outdoor ( $/ / O$ ) ratio of concentrations of both pollutants was higher than unity at both preschools (TVOC: I/ $\mathrm{O}=1.3-1.9$ at P1, 1.3-1.4 at P2; $\mathrm{CO}_{2}: \mathrm{I} / \mathrm{O}=1.3-2.3$ at $\mathrm{P} 1,1.7-1.8$ at $\left.\mathrm{P} 2\right)$. In addition, $\mathrm{I} / \mathrm{O}$ ratios of $\mathrm{PM}_{2} .5$ concentrations $>1$ were attained with values ranging between from 1.06 to 1.69 at $\mathrm{P} 1$ and from 1.27 to 1.87 at P2. A different profile was noted for levels of $\mathrm{CO}$ which were signifi- cantly higher in preschool outdoor compared with indoor air of the selected rooms (respec- tively, for early morning and late afternoon per- iods: 0.62 versus $0.57 \mathrm{mg} / \mathrm{m}^{3}$ and 1.81 versus $1.52 \mathrm{mg} / \mathrm{m}^{3}$ at $\mathrm{P} 1 ; 0.41$ versus $0.36 \mathrm{mg} / \mathrm{m}^{3}$ and 0.62 versus $0.23 \mathrm{mg} / \mathrm{m}^{3}$ at P2). Similar observations were also found for concentrations of $\mathrm{O}_{3}(0.15$ versus 0.11 $\mathrm{mg} / \mathrm{m}^{3}$ during morning $\mathrm{hr}$ and 0.26 versus $0.13 \mathrm{mg} / \mathrm{m}^{3}$ for afternoons at $\mathrm{P} 1 ; 0.05$ versus 0.02 $\mathrm{mg} / \mathrm{m}^{3}$ for early morning periods and 0.19 versus $0.06 \mathrm{mg} / \mathrm{m}^{3}$ at the end of the school day at P2). For these pollutants ( $\mathrm{CO}$ and $\mathrm{O} 3), \mathrm{I} / \mathrm{O}$ ratios were below unity at both pre- schools $(\mathrm{CO}: 1 / \mathrm{O}=$ 0.84-0.92 and $0.37-0.89 ; \mathrm{O}_{3}: \mathrm{I} / \mathrm{O}=0.50-0.73$ and $0.31-0.4$, respectively, at $\mathrm{P} 1$ and $\mathrm{P} 2$ ). 
Table 1. Concentrations of formaldehyde $\left(\mathrm{mg} / \mathrm{m}^{3}\right)$ in indoor air of preschools $\mathrm{P} 1$ and P2.

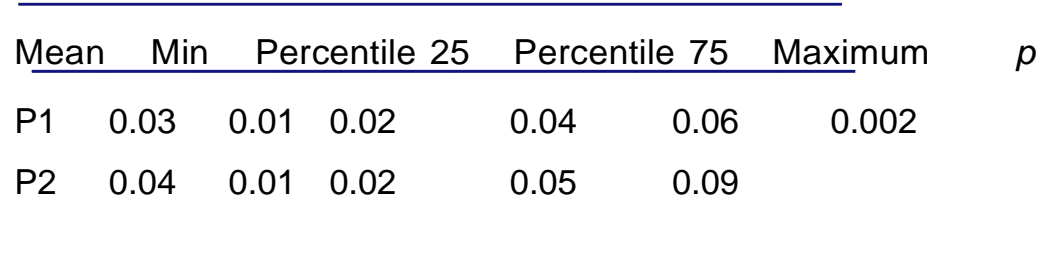

*Significant differences at $p \leq 0.05$ for nonparametric Mann-Whitney U-test between both preschools.

\section{Correlations between comfort parameters and pollutants}

Since both preschools were naturally ventilated, Spearman correlation coefficients ( $r$ ) were determined to estimate the influence of $\mathrm{T}, \mathrm{RH}$, and $\mathrm{CO}_{2}$ on levels of gaseous pollutants in indoor and outdoor air of both preschools. The degree of correlation may be used as an indicator of pollutant concentration dependency on the comfort parameters. A significant negative cor- relation was observed between $\mathrm{T}$ and $\mathrm{RH}$ in outdoor air of both preschools. Similar findings were noted in indoor air of rooms with correla- tions significant during the late afternoon per- iod. In outdoor air of both preschools, $\mathrm{CO}_{2}$ levels were significantly associated with $\mathrm{T}$ values with stronger correlations observed during early morning periods when the impact of traffic emissions was expected to be lower. Similar findings were found in indoor air of P2.

PM2.5 levels in indoor air were inversely related to respective concentration outdoors at both preschools indicating once again the influence of indoor sources. $\mathrm{RH}$ and $\mathrm{CO}_{2}$ values also showed a negative correlation with PM2.5 concentrations in indoor and outdoor air at both preschools.

Regarding the levels of gaseous pollutants in indoor air of preschools, $\mathrm{T}$ values were markedly associated with concentrations of $\mathrm{O}_{3}$, with greater correlations during the late afternoon periods. $\mathrm{RH}$ values were significantly correlated with TVOC in indoor air of both preschools. A significant asso- ciation was also noted between $\mathrm{RH}$ and $\mathrm{CO}_{2}$ levels during the afternoon period at $\mathrm{P} 1$ and $\mathrm{P} 2$. In addition, $\mathrm{CO}_{2}$ levels were markedly associated with concentrations of TVOC and CO monitored during the afternoon periods in indoor air of both preschools.

For preschool ambient air, $\mathrm{T}$ values were sig- nificantly associated with $\mathrm{CO}$ and $\mathrm{O}_{3}$ levels in both early morning and late afternoon periods. The correlations appeared to be greater during the afternoon periods at both preschools.

\section{Discussion}

Air pollutants

In what specifically applies to school environ- ments, the air, school activities, cleaning activities, cooking and emissions from printers, and photo- copy machines are the predominant PM indoor sources (Blondeau et al., 2005; Destaillats et al., 2008; Yi et al., 2016). Regarding preschools in this study, it was found that indoor levels were numerically higher than outdoors for both pre- schools. 
The determination of $\mathrm{I} / \mathrm{O}$ ratios enable estimation of an indoor/outdoor impact of a pol- lutant on indoor areas and the potential identification of their origin, with $1 / O$ ratios $>1$ indicating the existence of indoor emission sources. PM2.5 ratios suggested the presence of indoor sources predominantly due to re-suspen- sion of indoor dusts such as soil particles, cloth fibers, and building materials deterioration asso- ciated with schoolchildren activities. Yoon et al. (2011) and Amato et al. (2014) also noted that $\mathrm{PM} 2.5 \mathrm{l} / \mathrm{O}$ ratios were higher than unity in Korean and Spanish preschools. PM2.5 mean levels in indoor and outdoor air of both preschools were lower than the guideline quantities of $25 \mathrm{\mu g} / \mathrm{m}^{3}$ (Figure 2) (Decreto Lei no 118-2013, Portaria no. 353-A/2013; WHO, 2006). At both preschools, sampling campaigns were performed over 24-hr; however, the inclusion of the periods without stu- dents and their activities such as during nights when classrooms were empty and all windows and doors were closed may contribute to lower mean levels of $\mathrm{PM}_{2} .5$. The results obtained in this study were also lower than concentrations reported by Mainka and Zajusz-Zubek, (2015), Oliveira et al. (2015b, 2015c), and Rawi et al. (2015), which may be attributed to varying sam- pling strategies (8- or 24hr sampling periods), different seasonal and/or meteorological condi- tions and to various environmental characteristics. The findings of this study are in agreement with those of Madureira et al. (2012), who also detected negative correlations between $\mathrm{RH}$ and $\mathrm{CO}_{2}$ levels with $\mathrm{PM}_{10}, \mathrm{PM}_{2} .5$, and $\mathrm{PM}_{1}$ in indoor air of Portuguese primary schools. 

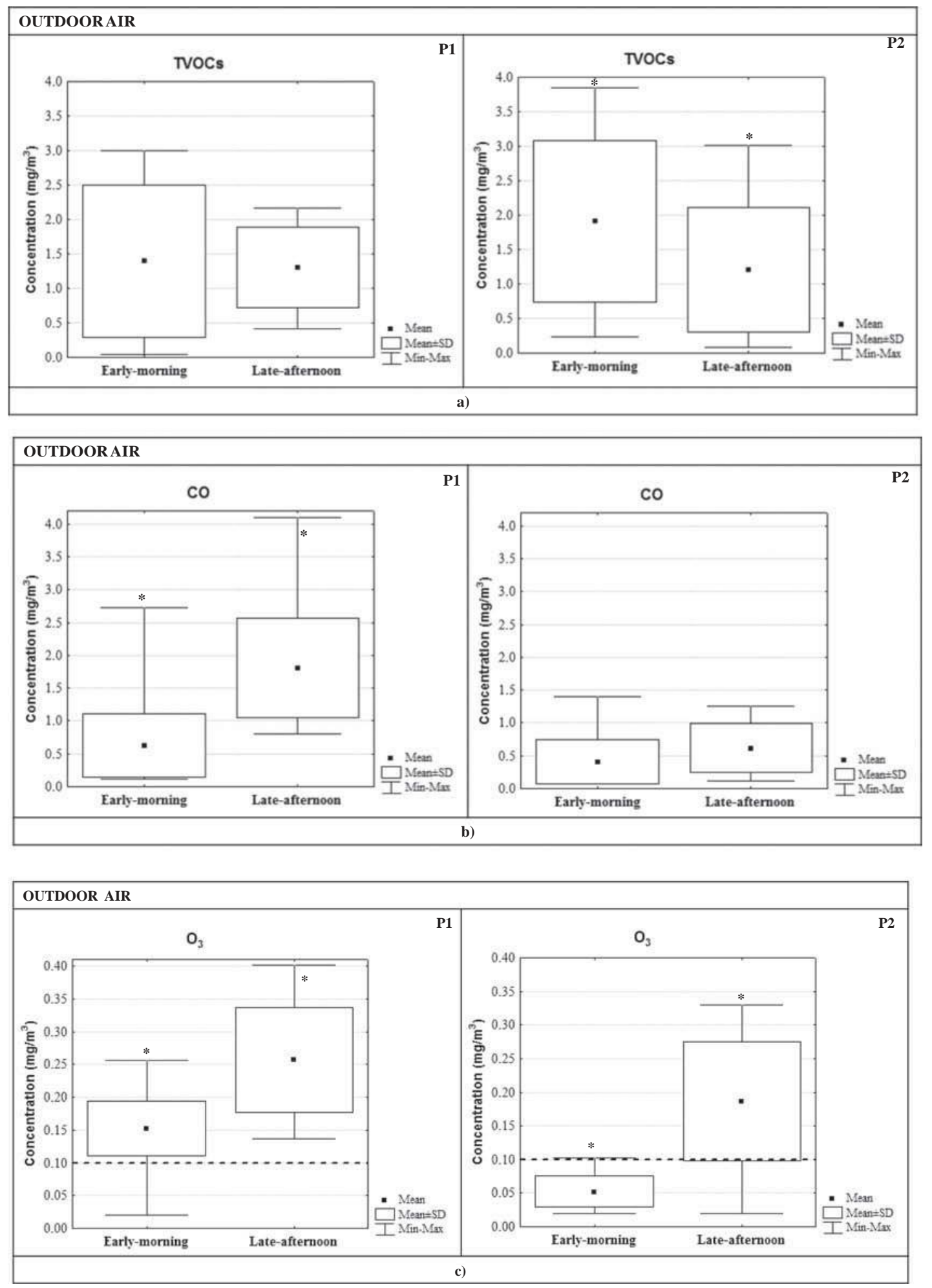

Figure 5. Levels of outdoor gaseous pollutants: a) total volatile organic compounds (TVOC); b) carbon monoxide (CO); c) ozone (O3) in the ambient air of preschool P1 and P2 $\left(\mathrm{mg} / \mathrm{m}^{3}\right)$. The horizontal dashed line represents WHO guideline of $0.1 \mathrm{mg} / \mathrm{m}^{3} \mathrm{for} \mathrm{O} 3(\mathrm{WHO}$, 2006). *Significant differences at $p \leq 0.05$ for nonparametric Mann-Whitney U-test between early morning and late afternoon pollutant concentrations for each preschool. 

At both preschools TVOC concentrations were significantly higher indoors than outdoors. TVOC I/O ratios suggested the prevalence of indoor sources, which is in agreement with observations of other investigators (Araújo-Martins et al., 2014; Mainka et al., 2015; Nunes et al., 2016; Rawi et al., 2015; Vassura et al., 2015; Yoon et al., 2011). Among the many gaseous pollutants examined by Vassura and coworkers (2015), VOC and princi- pally aldehydes were the compounds that pre- sented the highest indoor source emissions. Furniture and wooden products containing VOC- based resins as well as insulating materials, textiles, and products including paints, wallpapers, glues, adhesives, varnishes, and lacquers constitute the major sources of VOC in indoor environments (Franklin, 2007; McGwin Jr et al., 2010; Sarigiannis et al., 2011; Paciência et al., 2016). Cleaning products are a mixture of water and surfactants that contain VOC in their composi- tion. In addition, some electronic equipment such as computers, printers, and copier machines constitutes potential indoor sources of VOC (Destaillats et al., 2008). Outdoor TVOC levels observed at P1 were in similar range during early morning and late afternoon periods, while the respective levels indoors were significantly higher at the end of the school day, possibly due to accumulation of TVOC in indoor air as a conse- quence of deficient ventilation throughout the day. Regarding P2, higher concentrations of TVOC were found during the morning period than at the end of the day indicating a sufficient ventila- tion of the classroom throughout the day. At both preschools, early morning concentrations were higher than the respective outdoor levels, which might be due to accumulation of emissions during the night period as well as from cleaning (at the end of the classes). P2 classroom presented higher levels of TVOC than P1 educational playroom possibly due to room decoration and materials (children' handmade drawings and the presence of art craft supply that were suspended from the ceiling and/or glued to the walls). These findings are in agreement with the results reported by Rawi et al. (2015) and Godwin \& Batterman (2007). Indoor morning and afternoon concentrations of TVOC were higher than levels reported in the indoor air of Malay $(0.08 \mathrm{ppm}$ at Balakong area and $0.11 \mathrm{ppm}$ at Bangi area (Rawi et al., 2015)), Italian (0.008-0.04 ppm (Vassura et al., 2015)), and Korean $\left(0.59 \mathrm{mg} / \mathrm{m}^{3}, 0.07-1.93\right.$ $\mathrm{mg} / \mathrm{m}^{3}$ (Yoon et al., 2011)) preschools. Regarding Portuguese data, P1 and P2 TVOC indoor levels were also higher than concentrations reported in 14 primary schools situated in Lisbon during the spring season (37-317 $\mu \mathrm{g} / \mathrm{m}^{3}$ (Pegas et al., 2011b), $300 \pm 330 \mu \mathrm{g} / \mathrm{m}^{3}$ (Pegas et al., 2011a; Paciência et al. 2016). The mean concentrations of TVOC in indoor air of both preschools were 3-4 and 8-12- fold higher than the available recommendations for $\mathrm{IAQ}$ at Portuguese public buildings $\left(0.6 \mathrm{mg} / \mathrm{m}^{3}\right.$ over 8 -hr sampling period; Decreto Lei ํㅜ 118-2013, Portaria no. 353-A/2013) and European Collaborative Action report $\left(0.2 \mathrm{mg} / \mathrm{m}^{3}\right.$; ECA, 1997), respectively. It is important to mention that sampling of the gas pollutants was performed during short periods (15-20 $\mathrm{min}$ in the early morning and late afternoon hr) as recom- mended by the national guidelines of that time (minimum of 5 min sampling periods; Nota Técnica NT-SCE-02, 2006). At the end of 2013, the national guidelines were changed to 8-hr continuous sampling when assessing indoor air pollu- tion. Thus, the concentrations reported in this study need to be considered with caution as these values might not represent 8-hr exposure noted in the current national guidelines (Decreto Lei no 118-2013; Portaria no. 353-A/2013). However, the observed levels may represent risks for the respec- tive population of children at P1 and P2 since exposure to VOC 
may irritate eyes, nose, and throat and produce headaches, nausea, damage to the liver, kidneys, as well as some neurological symptoms (Annesi-Maesano et al., 2013; Demirel et al., 2014; Le Cann et al., 2011; Paciência et al., 2016; Sarigiannis et al., 2011; WHO, 2010); increased asthma severity, allergy, and airway inflammation in children were also reported pre- viously (Annesi-Maesano et al., 2013; Franklin, 2007; Lee et al., 2014; McGwin Jr et al., 2010; Zhao et al., 2008; Paciência et al., 2016). Further, highly reactive unsaturated carbon-carbon $\mathrm{VOC}$ may react with $\mathrm{O}_{3}$, which results in production of short lived and highly irritating pollutants that may also produce long-term adverse health effects. Future studies need to include the assessment of some other specific (individual) VOC, such as benzene, toluene, styrene, trichloroethylene, and tetrachloroethylene that are known to produce adverse health effects (Portaria no. 353-A/2013; Valcke \& Haddad, 2015).

Formaldehyde is one of the most studied VOC (Weschler, 2009). The predominant sources of formaldehyde in indoor air in Portuguese preschools are insulating materials, plywood furniture con- taining formaldehyde-based resins as well as water-based paints, and cleaning agents among other building materials that contain urea formal- dehyde resins (Franklin, 2007; Sarigiannis et al., 2011). Indoor levels of formaldehyde at Portuguese preschools were within the range reported by Yoon et al. (2011) in Korean pre- schools but higher than those observed for Italian preschools (Vassura et al., 2015). As formaldehyde exposure may induce both short- and long-term adverse health effects, a guideline value of $0.1 \mathrm{mg} / \mathrm{m}^{3}$ was recommended in order to prevent sensory irritation for short-term exposure (30 min) in the general population; $0.21 \mathrm{mg} / \mathrm{m}^{3}$ was recommended for chronic effects, including cancer (Decreto Lei no 118-2013, Portaria no. 353-A/2013; WHO, 2010). In the rooms of both preschools, formalde- hyde levels were well below those limits.

Indoor levels of $\mathrm{CO}$ are mostly attributed to emissions of combustion sources that may occur in indoor environments and from infiltration of ambient air. The mean early morning and late afternoon indoor levels of $\mathrm{CO}$ at both preschools were similar to indoor concentrations reported for urban Korean preschools (Yoon et al., 2011) and lower than levels found at Balakong and Bangi area at Malay preschools (Rawi et al., 2015). Regarding European countries, Vassura et al. (2015) examined the IAQ in Italian preschools located at a suburban area of the province of Bologna and detected lower levels of $\mathrm{CO}$ than in this study. It should be noted that indoor levels of $\mathrm{CO}$ depend upon the interaction of different inter- related factors, namely type, nature, and number of $\mathrm{CO}$ sources as well as building characteristics, infiltration, and/or ventilation rates and levels of $\mathrm{CO}$ in outdoor areas (EHC, 1999) which might account for the observed differences. Overall, both indoor and outdoor $\mathrm{CO}$ concentrations were lower than the established value of $10 \mathrm{mg} / \mathrm{m}^{3}$ (8-hr mean) set in national legislation (Decreto Lei no 118-2013, Portaria no. 353A/2013; European Union, 2008; WHO, 2010). I/O ratios demonstrated that outdoor air penetration was the predominant indoor source at P1 and P2, in agree- ment with findings reported by Branco et al (2015b), Nunes et al. (2016), and Yoon et al (2011). Differences between indoor and outdoor CO levels were higher at $\mathrm{P} 1$ than at $\mathrm{P} 2$ (Figures 3 and 5), possibly due to greater traffic density. Traffic emissions were reported as the major source of ambient CO in Oporto, Portugal (Slezakova et al., 2011).

According to Portuguese legislation, a maxi- mum reference concentration of $0.2 \mathrm{mg} / \mathrm{m}^{3}$ is 
recommended for $\mathrm{O}_{3}$ indoor air in Portuguese buildings (Nota Técnica NT-SEE-02, 2006). During the sampling campaigns, $\mathrm{O}_{3}$ indoor con- centrations were significantly higher at the end of the school day than during the morning periods, with total mean always below the maximum limit of $0.2 \mathrm{mg} / \mathrm{m}^{3}$.

However, at P1, a maximal concen- tration of $0.23 \mathrm{mg} / \mathrm{m}^{3}$ was reached at end of the school day (Figure 3). The predominant indoor sources for $\mathrm{O}_{3}$ include electronic equipment such as old printers and photocopy machines as well as air humidifiers (Destaillats et al., 2008), but such equipment was not used in the rooms of both preschools. In addition, P1 levels were higher than those observed at $P 2$. The $1 / O$ ratios sug- gested infiltration of outdoor emissions as the major source of $\mathrm{O}_{3}$ indoors, which agrees with data reported in previous studies (Branco et al., 2015b; Demircigil et al., 2014; Demirel et al., 2014). In 2014, the WHO daily maximum 8-hr mean concentration was lowered from 0.12 to $0.1 \mathrm{mg} / \mathrm{m}^{3}$ based on conclusive associations between daily mortality and $\mathrm{O}_{3}$ concentrations (EEA, 2015). The total mean outdoor concentrations exceeded the guideline of 0.1 $\mathrm{mg} / \mathrm{m}^{3}$ (WHO, 2006), reaching maximal levels of $0.4 \mathrm{mg} / \mathrm{m}^{3}$ and

$0.33 \mathrm{mg} / \mathrm{m}^{3}$ during the end of school day at P1 and P2, respectively. The EEA pointed out that during 2013 the daily maximum of $0.1 \mathrm{mg} / \mathrm{m}^{3}$ was exceeded more than 25 -fold in 18 of the 28 European Union countries (EEA, 2015) with the highest concentrations observed in some Mediterranean countries, including Portugal.

The sampling campaigns performed in both preschools monitored indoor and outdoor levels of relevant pollutants during limited periods of the school day (15-20 $\mathrm{min}$ in the early morning and 15-20 $\min$ at late afternoon). Since the national and international organizations recommend mon- itoring during a consecutive period of 8-hr, the levels reported in this study may not represent the overall 8-hr mean preschool children exposure. However, it is expected that early morning and late afternoon levels might include the overall ranges of schoolchildren exposure at preschools.

\section{Comfort parameters}

Thermal comfort may exert a significant impact on the general well-being and daily performance of building occupants (Mendes et al., 2013). Concerning IAQ, the Portuguese legislation recommends indoor $\mathrm{T}$ ranging from $20^{\circ} \mathrm{C}$ for the cooling season (winter) to $25^{\circ} \mathrm{C}$ during the hot season (summer) and $\mathrm{RH}$ of $50 \%$ during the overall year (Decreto Lei $\mathrm{n}^{\circ}$ 118-2013). This investigation was performed during spring and beginning of summer, and the obtained means of $\mathrm{T}$ and $\mathrm{RH}$ at both P1 and P2 schools (Table 2) were generally within the recommen- dations for indoor air. The considered preschools were both naturally ventilated, and thus, fluctuations of $\mathrm{T}$ and $\mathrm{RH}$ were a conse- quence of local climate conditions. The negative correlations observed between $\mathrm{T}$ and $\mathrm{RH}$ were expected since the increase in $\mathrm{T}$ is frequently associated with a reduction in $\mathrm{RH}$ values. Humidity is one of the critical factors that affect emissions of VOC from building materials (Huang et al., 2016). In this study, it was found that $\mathrm{RH}$ values were significantly corre- lated with levels of TVOC in indoor air in both preschools. It is known that higher $\mathrm{T}, \mathrm{RH}$, and larger wood-based surfaces promote emission of VOC from different 
construction materials (Sakai et al., 2004; Wolkoff \& Nielsen, 2010). Several investigators examined wood-based pro- ducts containing urea-formaldehyde glue and reported that VOC emissions are proportional to $\mathrm{RH}$ at a specific $\mathrm{T}$ (Myers, 1985; Van Netten et al., 1989), while $\mathrm{T}$ dependence is more com- plex (Zhang et al., 2007).

The number of occupants and their activities inside a room also influences IAQ. The American Society of Heating, Refrigerating, and Air- Conditioning Engineers (ASHRAE) recommend a maximum of 25 occupants (5-8 years old) for an acceptable IAQ in a room with $100 \mathrm{~m}^{2}$ (ASHRAE, 2013). National regulation estimates a mean occu- pation of 20-25 children per each classroom (Despacho $n^{0}$ 50481B/2013). Occupation rates at P1 exceeded those recommendations on some school days, particularly during the afternoon peri- ods at P1 (18-40 children). Occupants are respon- sible for the ventilation status of indoor environments through control of the ventilation system and/or the opening of windows. Exhaled air is usually the largest source of $\mathrm{CO}_{2}$ in class- rooms, and thus, it is frequently used as a screening tool to evaluate if adequate volumes of fresh outdoor air are being introduced indoors. Therefore, $\mathrm{CO}_{2}$ might be used as an efficient indicator of occupancy and ventilation status in indoor microenvironments. The early morning and late afternoon mean indoor concentrations of $\mathrm{CO}_{2}$ were below the protective guideline of $2250 \mathrm{mg} / \mathrm{m}^{3}$ (Portaria no. 353-A/ 2013). However, during the afternoon periods, levels of $\mathrm{CO}_{2}$ exceeded that recommendation (Figure 4a). At P1, the maximal levels of $\mathrm{CO}_{2}$ exceeded the $30 \%$ margin of tolerance $\left(2925 \mathrm{mg} / \mathrm{m}^{3}\right)$ that might be applied when no mechanical ventilation is being utilized at the selected indoor rooms (Portaria no. 353-A/2013). It is important to note that during afternoon periods, 3- to 5-year-old preschool chil- dren (principally the youngest ones) slept for $2 \mathrm{hr}$ after lunch (Table 2S). During that time, windows and doors were kept closed, which probably con- tributed to the lower air exchange rate and thus higher $\mathrm{CO}_{2}$ indoors, especially at $\mathrm{P} 1$, where the number of children was greater. Similar observa- tions were reported previously in urban nurseries (Branco et al., 2015a; Yang et al., 2009; Yoon et al., 2011). Inadequate ventilation may be generated by insufficient air volume, high levels of recirculation, incorrect placement of the ventilation points, and deficient distribution that exits certain areas without ventilation (Fernández et al., 2013). Ambient levels of $\mathrm{CO}_{2}$ ranged between from 688 to $1100 \mathrm{mg} / \mathrm{m}^{3}$ at P1 and from 581 to $842 \mathrm{mg} / \mathrm{m}^{3}$ at P2 (Figure 4b). The outdoor concentrations of $\mathrm{CO}_{2}$ at the Oporto preschool (P1) were higher than levels reported during the summer season $\left(180-443 \mathrm{mg} / \mathrm{m}^{3}\right.$ (Madureira et al., 2012) and 280-520 $\mathrm{mg} / \mathrm{m}^{3}$ 
(Mendes et al., 2013)), but similar to concentrations detected by Mendes et al. (2013) during a winter season $\left(250-2050 \mathrm{mg} / \mathrm{m}^{3}\right)$. It is known that different atmospheric conditions and varying local sources markedly influence levels of $\mathrm{CO}_{2}$ and ambient air gaseous pollutants. As expected, indoor $\mathrm{CO}_{2}$ concentrations were always higher than outdoors at both preschools (Figure 4), mainly due to room occupancy and some apparent ventilation deficien- cies. WHO (2000) and ASHRAE (2013) recommended a minimum permissible $\mathrm{CO}_{2}$ concentration of $1800 \mathrm{mg} / \mathrm{m}^{3}$. At both preschools, differences between indoor and outdoor $\mathrm{CO}_{2}$ means were, respectively, 276 and $1057 \mathrm{mg} / \mathrm{m}^{3}$ at $\mathrm{P} 1$ for early morning and late afternoon periods, and 533 and $614 \mathrm{mg} / \mathrm{m}^{3}$ at P2, always below the $1800 \mathrm{mg} / \mathrm{m}^{3}$ permissible limit even at the end of the school day. Shendell and colleagues (2004) examined the asso- ciation of student absence with measurements of indoor minus outdoor $\mathrm{CO}_{2}$ concentrations and found that $45 \%$ of the 434 American studied class- rooms had short-term CO2 levels above $1800 \mathrm{mg} / \mathrm{m}^{3}$. Shendell et al (2004) indicated that an $1800 \mathrm{mg} / \mathrm{m}^{3}$ increase in $\mathrm{CO}_{2}$ indoors compared to outdoor concentrations might promote a relative rise of 10-20\% of student absenteeism. Recently, Bakó- Biró et al. (2012) and Ferreira and Cardoso (2014) presented evidence that low ventilation rates in classrooms, that is, $\mathrm{CO}_{2}$ concentrations > $1800 \mathrm{mg} / \mathrm{m}^{3}$, significantly reduced children's attention and vigilance, affecting negatively memory and con- centration. In conclusion, this study estimated IAQ in Portuguese preschools. Overall, the attained results suggested that insufficient ventilation throughout the school day and the impact of out- door air penetration indoors was the predominant factors that affected IAQ at the examined preschools.

\section{Funding}

This work was supported by European Union (FEDER funds through COMPETE) and National Funds (Fundação para a Ciência e Tecnologia, FCT) through projects UID/QUI/ 50006/2013, POCI-01-0145FEDER-007265, and POCI-01-0145-FEDER-006939, by the FCT/MEC with national funds and co-funded by FEDER in the scope of the P2020 Partnership Agreement. Additional financial support was provided by FCT through the fellowships SFRH/BD/80113/2011 and SFRH/BPD/105100/2014. 


\section{References}

Alves, C. A., Urban, R. C., Pegas, P. N., and Nunes, T. 2014. Indoor/Outdoor relationships between PM10 and asso- ciated organic compounds in a primary school. Aerosol Air Qual. Res. 14:86-98.

Amato, F., Rivas, I., Viana, M., Moreno, T., Bouso, L., Reche, C., Àlvarez-Pedrerol, M., Alastuey, A., Sunyer, J., and Querol, X. 2014. Sources of indoor and outdoor PM2.5 concentrations in primary schools. Sci. Total Environ. 490: 757-765.

Annesi-Maesano, I., Baiz, N., Banerjee, S., Rudnai, P., and Rive,

S. 2013. Indoor air quality and sources in schools and related health effects. J. Toxicol. Environ. Health. B 16: 491-550.

Annesi-Maesano, I., Hulin, M., Lavaud, F., Raherison, C., Kopferschmitt, C., de Blay, F., Charpin, D. A., and Denis,

C. 2012. Poor air quality in classrooms related to asthma and rhinitis in primary schoolchildren of the French 6 Cities Study. Thorax 67: 682-688.

Araújo-Martins, J., Carreiro Martins, P., Viegas, J., Aelenei, D.,

Cano, M. M., Teixeira, J. P., Paixão, P., Papoila, A. L., Leiria- Pinto, P., Pedro, C., Rosado-Pinto, J., AnnesiMaesano, I., and Neuparth, N. 2014. Environment and Health in children day care centres (ENVIRH) - study rationale and protocol. Rev. Portuguesa Pneumol. 20:311-323.

ASHRAE. 2013. ASHRAE Standard 62.1. 2007. Ventilation for Acceptable Indoor Air Quality, 46. Atlanta, GA: American Society of Heating, Refrigerating and Air- Conditioning Engineers.

Bakó-Biró, Z., Clements-Croome, D. J., Kochhar, N., Awbi, H. B., and Williams, M. J. 2012. Ventilation rates in schools and pupils' performance. Build. Environ. 48: 215-223.

Bateson, T. F., and Schwartz, J. 2008. Children's response to air pollutants. J. Toxicol. Environ Health A 71: 238-243. Blondeau, P., lordache, V., Poupard, O., Genin, D., and

Allard, F. 2005. Relationship between outdoor and indoor air quality in eight French schools. Indoor Air 15: 2-12.

Branco, P. T. B. S., Alvim-Ferraz, M. C. M., Martins, F. G., and Sousa, S. I. V. 2015a. Children's exposure to indoor air in urban nurseries - part I: $\mathrm{CO} 2$ and comfort assessment. Environ. Res. 140: 1-9.

Branco, P. T. B. S., Alvim-Ferraz, M. C. M., Martins, F. G., and Sousa, S. I. V. 2014. Indoor air quality in urban nurseries at Porto city: particulate matter assessment. Atmos. Environ. 84: 133-143.

Branco, P. T. B. S., Nunes, R. A. O., Alvim-Ferraz, M. C. M.,

Martins, F. G., and Sousa, S. I. V. 2015b. Children's expo- sure to indoor air in urban nurseries - part II: gaseous pollutants' assessment. Environ. Res. 142: 662-670.

Burtscher, H., and Schüepp, K. 2012. The occurrence of ultrafine particles in the specific environment of children. Paediatr. Respir. Rev. 13: 89-94.

Carreiro-Martins, P., Viegas, J., Papoila, A. L., Aelenei, D., Caires, I., Araújo-Martins, J., Gaspar-Marques, J., Cano, M. M., Mendes, A. S., Virella, D., Rosado-Pinto, J., Leiria-Pinto, P., Annesi-Maesano, I., and Neuparth, N. 2014. $\mathrm{CO} 2$ concentration in day care centres is related to wheezing in attending children. Eur. J. Pediatr. 173: 1041-1049. 
Cavaleiro Rufo, J., Madureira, J., Paciência, I., Slezakova, K., Pereira, M. C., Pereira, C., Teixeira, J. P., Pinto, M., Moreira, A., and de Oliveira Fernandes, E. 2015. Exposure of children to ultrafine particles in primary schools in Portugal. J. Toxicol. Environ. Health A 78: 904-914.

Costa, S, Ferreira, J., Silveira, C., Costa, C., Lopes, D., Relvas, H., Borrego, C., Roebeling, P., Miranda, A. I., and Teixeira,

J. P. 2014. Integrating health on air quality assessment - review report on health risks of two major European out- door air pollutants: PM and NO2. J. Toxicol. Environ. Health B17:307-340.

Cyprowski, M., Buczyńska, A., and Szadkowska-Stańczyk, I.

2013. Indoor allergens in settled dust from kindergartens in city of Łódź, Poland. Int. J. Occup. Med. Environ. Health 26: 890-899.

Decreto Lei no 118/2013. Ministério da Economia e do Emprego. Diário da Republica, 235 1aㅗ série. Available at: https://www.academiaadene.pt/download/pt/decreto-lei-n- 1182013-de-20-de-agosto.pdf. Accessed in September 2016.

Demircigil, G. Ç., Erdem, O., Gaga, E. O., Altug, H., Demirel, G., Örnektekin, S., Dögeroglu, T., van Doorn, W., and Burgaz, S. 2014. Cytogenetic biomonitoring of primary school children exposed to air pollutants: Micronuclei analysis of buccal epithelial cells. Environ. Sci. Pollut. Res. 21: 1197-1207.

Demirel, G., Özden, T., Döğeroğlu, T., and Gaga, E. O. 2014. Personal exposure of primary school children to BTEX, NO2 and ozone in Eskişehir, Turkey: relationship with indoor/outdoor concentrations and risk assessment. Sci. Total Environ. 473-474:537-548.

Despacho no 5048-1B2013 - Ministério da Educação e

Ciência. Diário da República $72, \quad 2^{\text {a }}$ série. Available at: https://www.portaldasescolas.pt/imageserver/plumtree/por tal/matnet/Despacho_5048B_2013.pdf. Accessed in September 2016.

Destaillats, H., Maddalena, R. L., Singer, B. C., Hodgson, A. T., and McKone, T. E. 2008. Indoor pollutants emitted by office equipment: a review of reported data and informa- tion needs. Atmos. Environ. 42: 13711388.

ECA. 1997. European Collaborative Action. Indoor air and its impact on man. Report 19. Total volatile organic com- pounds (TVOC) in indoor air quality Investigations. European Commission, Joint Research Centre, Environment Institute. Office for Official Publications of the European Communities. Luxembourg.EEA. 2015. Air Quality in Europe - 2015 Report. European Environment Agency. Publications Office of the European Union. Luxembourg. ISSN 1977-8449.

EHC. 1999. "Chemistry and analytical methods." Environmental Health Criteria 2013: Carbon Monoxide. World and Health Organization, Geneva, 2nd edn. p20-133.

European Union. 2008. Directive 2008/50/EC of the European Parliament and of the Council on ambient air quality and cleaner air for Europe. Off. J. Eur. Union L152: 1-44.

Fernández, L. C., Alvarez, R. F., González-Barcala, F. J., and Portal, J. A. R. 2013. Indoor air contaminants and their impact on respiratory pathologies. Arch. Bronchopneumol. 49:22-27.

Ferreira, A. M. C., and Cardoso, S. M. 2013. Exploratory study of air quality in elementary schools, Coimbra, Portugal. Rev. Saúde Pública 47: 1059-1068.

Ferreira, A. M. C., and Cardoso, S. M. 2014. Indoor air quality and health in schools. J. Bras. Pneumol. 40: 259- 268.

Fonseca, J., Slezakova, K., Morais, S., and Pereira, M. C. 2014. Assessment of ultrafine particles in Portuguese preschools: levels and exposure levels. Indoor Air 24: 618-628. 
Franklin, P. J. 2007. Indoor air quality and respiratory health

of children. Paediat. Respir. Rev. 8: 281-286. Gładyszewska-Fiedoruk, K. 2013. Correlations of air humidity and carbon dioxide concentration in the kindergarten.

Energy Build. 62: 45-50.

Godwin, C., and Batterman, S. 2007. Indoor air quality in Michigan schools. Indoor Air 17: 109-121.

Guo, H., Morawska, L., He, C., Zhang, Y. L., Ayoko, G., and

Cao, M. 2010. Characterization of particle number con- centrations and PM2.5 in a school: influence of outdoor air pollution on indoor air. Environ. Sci. Pollut. Res. 17: 1268- 1278.

Huang, S., Xiong, J., Cai, C., Xu, W., and Zhang, Y. 2016. Influence of humidity on the initial emittable concentra- tion of formaldehyde and hexaldehyde in building materi- als: experimental observation and correlation. Sci. Rep. 6: 23388.

IARC. 2006. International Agency for Research on Cancer. Formaldehyde, 2-butoxyethanol and 1tertbutoxypropan- 2-ol. IARC Monographs on the Evaluation of the Carcinogenic Risk of Chemicals to Humans. 88. 39-325.

IARC. 2016. International Agency for Research on Cancer. Outdoor air pollution IARC Monographs on the evalua- tion of carcinogenic risks to humans. 109. 1-454.

Kim, K.-H., Ara Jahan, S., Kabir, E., and Brown, R. J. C. 2013. A review of airborne polycyclic aromatic hydrocarbons (PAHs) and their human health effects. Environ. Int. 60: 71-80.

Latif, M. T., Yong, S. M., Saad, A., Mohamad, N., Baharudin,

N. H., Mokhtar, M. B., and Tahir, N. M. 2014. Composition of heavy metals in indoor dust and their possible exposure: a case study of preschool children in Malaysia. Air Qual. Atmos. Health 7:181-193.

Le Cann, P., Bonvallot, N., Glorennec, P., Deguen, S., Goeury, C., and Le Bot, B. 2011. Indoor environment and chil- dren's health: recent developments in chemical, biological, physical and social aspects. Int. J. Hyg. Environ. Health 215: 1-18.

Lee, J. Y., Lee, S-B., and Bae, G.-N. 2014. A review of the association between air pollutant exposure and allergic diseases in children. Atmos. Pollut. Res. 5: 616-629.

Macedo, A., Magalhães, O., Brito, A., and Mayan, O. 2013.

Characterization of indoor environmental quality in pri- mary schools in Maia: a Portuguese case study. Human Ecol. Risk Assess. 19: 126-136.

Madureira, J., Paciência, I., and de Oliveira Fernandes, E.

2012. Levels and indoor-outdoor relationships of size-spe- cific particulate matter in naturally ventilated Portuguese schools. J. Toxicol. Environ. Health A 75: 1423-1436.

Madureira, J., Paciência, I., Ramos, E., Barros, H., Pereira, C.,

Teixeira, J. P., and de Oliveira Fernandes, E. 2015. Children's health and indoor air quality in primary schools and homes in Portugal - study design. J. Toxicol. Environ. Health A 78: 915-930.

Madureira, J., Pereira, C., Paciência, I. Teixeira, J. P., and de

Oliveira Fernandes, E. 2014. Identification and levels of airborne fungi in Portuguese primary schools. J. Toxicol. Environ. Health A 77:816-826.

Mainka, A., Brągoszewska, E., Kozielska, B., Pastuszka, J. S., and Zajusz-Zubek, E. 2015. Indoor air quality in urban nurseries in Gliwice, Poland: analysis of the case study. Atmos. Pollut. Res. 6: 1098-1104.

Mainka, A., and Zajusz-Zubek, E. 2015. Indoor air quality in

urban and rural preschools in Upper Silesia, Poland: par- ticulate matter and carbon dioxide. Int. J. 
Environ. Res. Public Health 12: 7697-7711.

Makri, A., Goveia, M., Balbus, J., and Parkin, R. 2004.

Children's susceptibility to chemicals: a review by devel- opmental stage. J. Toxicol. Environ. Health B 7: 417-435.

McGwin, Jr. G., Lienert, J., and Kennedy, Jr. J. I. 2010. Formaldehyde exposure and asthma in children: a sys- tematic review. Environ. Health Persp. 118:313-317.

Mendes, A., Pereira, C., Mendes, D., Aguiar, L., Neves, P.,

Silva, S., Batterman, S., and Teixeira, J. P. 2013. Indoor air quality and thermal comfort - results of a pilot study in elderly care centers in Portugal. J. Toxicol. Environ. Health A 76: 333-344.

Myers, G. 1985. The effects of temperature and humidity on

formaldehyde emission from UF-bonded boards: a litera- ture review. Forest Prod. J. 35: 20-31.

Nota Técnica NT-SCE-02. 2006. Metodologia para auditorias periódicas e QAl em edifícios de serviços existentes no âmbito do RSECE. Certificação Energética a Ar Interior de Edifícios. Available at: http://www.enviro.pt/index.php/ documentos?task=document.viewdoc\&id=14. Accessed in August 2016.

Nunes, R. A. O., Branco, P. T. B. S., Alvim-Ferraz, M. C. M., Martins, F. G., and Sousa, S. I. V. 2015. Particulate matter in rural and urban nursery schools in Portugal. Environ. Pollut. 202: 7-16.

Nunes, R. A. O., Branco, P. T. B. S., Alvim-Ferraz, F. G., and Sousa, S. I. V. 2016. Gaseous pollutants on rural and urban nursery schools in Northern Portugal. Environ. Pollut. 208: 2-15.

Oliveira, M., Slezakova, K., Delerue-Matos, C., Pereira, M., and Morais, S. 2015a. "Characterization of indoor air pol- lution in a Portuguese pre-school." Occupational Safety and Hygiene III, edited by P. M. Arezes, J. P. Baptista,

M. P. Barroso, P. Carneiro, P. Cordeiro, N. Costa, R. B. Melo, A. S. Miguel, and G. Perestrelo, 127130. Boca Raton, USA: CRC Press, Taylor and Francis Group.

Oliveira, M., Slezakova, K., Delerue-Matos, C., Pereira, M. C., and Morais, S. 2015b. Exposure to polycyclic aromatic hydrocarbons and assessment of potential risks in pre- schoolchildren. Environ. Sci. Pollut. Res. 22: 13892-13902. Oliveira, M., Slezakova, K., Delerue-Matos, C., Pereira, M. C., and Morais, S. 2015c. Polycyclic aromatic hydrocarbons: levels and phase distribution in preschool microenvironment. Indoor Air 25: 557-568.

Oliveira, M., Slezakova, K., Delerue-Matos, C., Pereira, M. C., and Morais, S. 2016a. Assessment of air quality in pre- school environments (3-5 years old children) with empha- sis on elemental composition of PM10 and PM2.5. Environ. Pollut. 214: 430-439.

Oliveira, M., Slezakova, K., Delerue-Matos, C., Pereira, M., and Morais, S. 2016b. "Assessment of gaseous pollutants in a preschool environment." Occupational Safety and Hygiene IV, edited by P. M. Arezes, J. P. Baptista, M. P. Barroso, P. Carneiro, P. Cordeiro, N. Costa, R. B. Melo, A.

S. Miguel, and G. Perestrelo, 51-55.Boca Raton, USA: CRC Press, Taylor and Francis Group.

Oliveira, M., Slezakova, K., Delerue-Matos, C., Pereira, M. C.,

and Morais, S. 2016c. Assessment of polycyclic aromatic hydrocarbons in indoor and outdoor air of preschool environments (3-5 years old children). Environ. Pollut. 208: 382-394.

Paciência, I., Madureira, J., Rufo, J., Moreira, A., and de Oliveira Fernandes, E. 2016. A systematic review of evidence and implications of spatial and seasonal varia- tions of volatile organic compounds (VOC) in indoor human environments. J. Toxicol. Environ. Health B 19: 47-64.

Pegas, P. N., Alves, C. A., Evtyugina, M. G., Nunes, T., 
Cerqueira, M., Franchi, M., Pio, C. A., Almeida, S. M., Cabo Verde, S., and Freitas, M. C. 2011 a. Seasonal evalua- tion of outdoor/indoor air quality in primary schools in Lisbon. J. Environ. Monit. 13:657667.

Pegas, P. N., Alves, C. A., Evtyugina, M. G., Nunes, T., Cerqueira, M., Franchi, M., Pio, C. A., Almeida, S. M., and Freitas, M. C. 2011b. Indoor air quality in elementary schools of Lisbon in spring. Environ. Geochem. Health 33: 455-468.

Pegas, P. N., Evtyugina, M. G., Alves, C. A., Nunes, T., Cerqueira, M., Franchi, M., Pio, C., Almeida, S. M., and Freitas, M. C. 2010. Outdoor/indoor air quality in primary schools in Lisbon: a preliminary study. Quim. Nova 33: 1145-1149.

Pegas, P. N., Nunes, T., Alves, C. A., Silva, J. R., Vieira, S. L. A., Caseiro, A., and Pio, C. A. 2012. Indoor and outdoor characterization of organic and inorganic compounds in city centre and suburban elementary schools of Aveiro, Portugal. Atmos. Environ. 55:80-89.

Pordata. 2016. Pordata - Base de dados Portugal

Contemporâneo. Available http://www.pordata.pt/

Municipios/Estabelecimentos+nos+ensinos+pr\%C3\%A9

+ escolar++b\%C3\%A1sico+e+secund\%C3\%A1rio+por+n\% C3\%ADvel+de+ensino-213 (Accessed August 2016).

Portaria 353-A/2013. Ministérios do Ambiente,

Ordenamento do Território e Energia, da Saúde e da solidariedade, Emprego e Segurança Social. Diário da Republica, $2351^{\underline{a}}$ série. Available at: https://www.acade miaadene.pt/download/pt/portaria-n-353a2013-recs-venti lacao-e-qai.pdf. Accessed in September 2016.

Rawi, N. A. M. N., Jalaludin, J., and Chua, P. C. 2015. Indoor Air Quality and Respiratory Health among Malay Preschool Children in Selangor. Hindawi Publishing Corporation BioMed Research International. doi:10.1155/2015/248178

Sakai, K., Norbäck, D., Mi, Y., Shibata, E., Kamijima, M., Yamada, T., and Takeuchi, Y. 2004. A comparison of indoor air pollutants in Japan and Sweden: formaldehyde, nitrogen dioxide, and chlorinated volatile organic com- pounds. Environ. Res. 94: 75-85.

Salvi, S. 2007. Health effects of ambient air pollution in children. Paediat. Respir. Rev. 8: 275-280.

Sarigiannis, D. A., Karakitsios, S. P., Gotti, A., Liakos, I. L., and Katsoyiannis, A. 2011. Exposure to major volatile organic compounds and carbonyls in European indoor environments and associated health risk. Environ. Int. 37: 743-765.

Shendell, D. G., Prill, R., Fisk, W. J., Apte, M. G., Blake, D., and Faulkner, D. 2004. Associations between classroom $\mathrm{CO} 2$ concentrations and student attendance in Washington and Idaho. Indoor Air 14: 333-341.

Slezakova, K., Castro, D., Begonha, A., Delerue-Matos, C., Alvim- Ferraz, M. C., Morais, S., and Pereira, M. C. 2011. Air pollution from traffic emissions in Oporto, Portugal: health and envir- onmental implications. Microchem. J. 99: 51-59.

Slezakova, K., Teixeira, C., Morais, S., and Pereira, M. C. 2015. Children's indoor exposures to (ultra)fine particles in an urban area: comparison between school and home environments. J. Toxicol. Environ. Health A 78: 886-896.

Valcke, M., and Haddad, S. 2015. Assessing human variability

in kinetics for exposures to multiple environmental che- micals: a physiologically based pharmacokinetic 
modeling case study with dichloromethane, benzene, toluene,ethylbenzene, and m-xylene. J. Toxicol. Environ. Health A 78: 409-431.

Van Netten, C., Shirtliffe, C., and Svec, J. 1989. Temperature and humidity dependence of formaldehyde release from selected building materials. Bull. Environ. Contam. Toxicol. 42: 558-565.

Vassura, I., Venturini, E., Bernardi, E., Passarini, F., and Settimo, G. 2015. Assessment of indoor pollution in a school environment through both passive and continuous sampling. Environ. Eng. Manage. J. 14: 17621770.

Weschler, C. J. 2009. Changes in indoor pollutants since the 1950s. Atmos. Environ. 4: 153-169.

Wichmann, J., Lind, T., Nilsson, M. A. M., and Bellander, T. 2010. PM2.5, soot and NO2 indoor-outdoor relationships at homes, pre-schools and schools in Stockholm, Sweden. Atmos. Environ. 44: 4536-4544.

Wolkoff, P., and Nielsen, G. D. 2010. Non-cancer effects of formaldehyde and relevance for setting an indoor air guideline. Environ. Int. 36: 788-799.

WHO. 2000. World Health Organization. Air Quality Guidelines for Europe. Copenhagen, Denmark: World Health Organization Regional Office for Europe.

WHO. 2006. World Health Organization. Air Quality Guidelines Global Update 2005. Copenhagen, Denmark: World Health Organization Regional Office for Europe.

WHO. 2010. World Health Organization Guidelines for Indoor Air Quality: Selected Pollutants. Copenhagen, Denmark: World Health Organization Regional Office for Europe.

Yang, W., Sohn, J., Kim, J., Son, B., and Park, J. 2009. Indoor air quality investigation according to age of the school buildings in Korea. J. Environ. Manage. 90: 348-354.

Yi, J., Lebouf, R. F., Duling, M. G., Nurkiewicz, T., Chen, B.

T., Schwegler-Berry, D., Virji, M. A., and Stefaniak, A. B. 2016. Emission of particulate matter from a desktop three- dimensional (3D) printer. J. Toxicol. Environ. Health A. 79: 453-465.

Yoon, C., Lee, K., and Park, D. 2011. Indoor air quality differences between urban and rural preschools in Korea. Environ. Sci. Pollut. Res. 18: 333-345.

Zhang, Y., Luo, X., Wang, X., Qian, K., and Zhao, R. 2007.

Influence of temperature on formaldehyde emission para- meters of dry building materials. Atmos. Environ. 41: 3203-3216.

Zhao, Z., Zhang, Z., Wang, Z., Ferm, M., Liang, Y., and Norbäck, D. 2008. Asthmatic symptoms among pupils in relation to winter indoor and outdoor pollution in schools in Taiyuan, China. Environ. Health Persp. 116: 90-97. 